\title{
TWEETS AND MOBILISATION: COLLECTIVE ACTION THEORY AND SOCIAL MEDIA
}

\section{Cody McClain Brown}

Izvorni znanstveni rad / DOI: 10.20901/ms.8.15.2 / Primljeno: 03.04.2017.

ABSTRACT This article examines the relationship between social protest and social media from the theoretical perspective of the Collective Action Research Program. While the literature shows strong empirical evidence for a positive relationship between social media use and incidents of social protest, the theoretical underpinnings of this relationship remain contested and often unspecified. In order to provide a stronger theoretical basis for this relationship this paper explores theories of collective action, focusing on how social media can assist in solving the dissident collective action problem. It argues that using collective action theory to understand social media and protest can better inform our understanding of how and why social media shares a positive relationship with incidents of social protest.

KEY WORDS

SOCIAL MEDIA, SOCIAL PROTEST, CONTENTIOUS POLITICS, COLLECTIVE ACTION THEORY

Author note

Cody McClain Brown :: University of Zagreb, Faculty of Political Science, Zagreb, Croatia :: codymcclain@gmail.com 


\section{INTRODUCTION}

In April 2009, 10000 Moldavians, amid allegations of voter fraud, protested the outcome of the parliamentary elections in Chisinau (Barry, 2009). It was reported that the protesters used social media to help mobilise and organise the event (Barry, 2009). A few months later in June 2009, protesters in Iran began a months long campaign against the result of the Iranian presidential elections. Similarly to the protests in Moldova, social media, particularly Twitter, were seen as instrumental in aiding protesters' ability to mobilise. The US State Department even requested that Twitter postpone an update of its network so that it would not conflict with the protesters' ability to tweet (Grossman, 2009). In 2011, protests in Tunisia overthrew the country's dictatorial regime. Once again Twitter was seen as great asset to the country's dissidents (Delany, 2011). These protests were followed by similar protests in Egypt a few months later, which resulted in the resignation of Egypt's long ruling dictator, Hosni Mubarak. Since then, these events have subsequently been included under the title of the 'Twitter Revolutions'.

Within the literature a debate has emerged in which skeptics view online activism as little more than 'feel good' expressions of preference that have little influence on mobilisation or participation in physical protest events (Morozov, 2009; Gladwell, 2010). However, an ample amount of research has offered an alternative perspective, arguing, and demonstrating that online activism shares a positive relationship with mobilisation for the purposes of social protest (Barbera et al., 2015; Gil de Zúñiga et al., 2012; Bastos et al., 2015; Bastos et al., 2014; Tufekci and Wilson, 2012; Segerberg and Bennett 2011; Bennett and Segerberg 2012). For example, Homero Gil de Zúñiga and colleagues find that "frequent users of social media were nearly 11 times more likely to participate in street demonstrations than were nonusers" (2012: 12) during demonstrations in Chile. Marco Bastos and colleagues (2015) equally demonstrate a strong relationship between an increase in online protest activity and a later onsite presence at a protest event for protests in Spain and the Occupy Movement. Zeynep Tufekci and Christopher Wilson's (2012) work on the Arab Spring in Egypt found a statistically significant correlation between an individual's use of social media and attendance at protest events.

Therefore it seems quite clear that social media has become a useful tool for dissidents and protest. While there seems to be a strong consensus within the literature about the presence of a positive relationship between protest and social media use, there does not seem to be a consensus concerning the theoretical underpinnings that support this relationship (Breuer et al., 2015; Wolfsfeld et al., 2013; Tufekci, 2014). Some of the research structures its work around Resource Mobilisation Theory (McCarthy and Zald, 1977; Conover et al., 2013), while other work utilises the concept of Opportunity Structures (McAdam et al., 2001; Bennett and Segerberg 2012), others seem to combine various approaches (Breuer et al., 2015). For example Wolfsfeld and colleagues (2013) offer a very nuanced view in which the political context and contingencies are given priority, while other work focuses more on the relationship between social media and protest, observing and noting its dynamics, while paying less attention to the theoretical aspects of that relationship (Barbera et al., 2015; Gil de Zúñiga et al., 2012). Essentially, there seems to be 
little agreement on the theoretical underpinnings of how social media helps individuals to collectively act, only that it does. This is not that surprising given how difficult it can be to observe the causal the mechanisms involved, the many factors involved with mobilisation (Barbera et al., 2015), the debate within the protest literature itself (Lichbach, 1998a; Lichbach, 1997), the fact that social media is a relatively new phenomenon, and debates on how to conceptualise what is actually being studied (Theocharis, 2015).

Social media is considered to be such an influential phenomenon in the world of contentious politics that its use in social protest has even been argued to have done away with the collective action problem altogether. Tufekci (2014) expresses this sentiment, "Olson's famous 'free rider' problem is thus largely irrelevant to most modern protests in nontotalitarian states: people who show up for protests are not accepting an onerous burden but rather are attracted by the engaged, powerful effervescence the protests create"(Tufekci, 2014: 207).

At first glance it seems hard to argue with this notion, given the research to date, and the advent of such events as the Arab Spring, Occupy Wall Street, protests in Spain, Chile and elsewhere over the last decade. Anita Breuer and colleagues (2015) point out that an emphasis on the collective action problem should indicate that protest is unlikely, and yet protest seems to be occurring regularly.

However, by assuming away the collective action problem we may be losing a potential area of theoretical consensus where the relationship between social media and social protest can be better understood and supported. In this paper I offer that we should not see social media as making the collective action or 'free rider' problem irrelevant, rather by focusing on the ways in which social media facilitates solutions to solving the collective action problem we can better understand and reconcile the relationship between protest and social media. Doing so, could help to further reduced the debate between 'slacktivist' skeptics and non-skeptics by providing a robust, unified theoretical framework through which research can find strong explanations as to why social media can so easily facilitate solutions to the collective action problem.

In this paper I explore the relationship between social media and social protest from the perspective of Mark Lichbach's Collective Action Research Program (CARP) (1998a). For the purposes of this paper I look at CARP's theoretical understanding of how social media helps facilitate mass, social protest. For these purposes I use the following definition of social media: "forms of electronic communication (as websites for social networking and microblogging) through which users create online communities to share information, ideas, personal messages, and other content (as videos)" (Merriam-Webster, 2017).

While I am not the first to explore this area, I do take an approach that differentiates this paper from those found elsewhere in the literature (Bennett and Segerberg, 2012; Gerbaudo, 2012; Tufekci and Wilson, 2012; Wolfsfeld et al., 2013; Tufekci, 2014; Breuer et al., 2015) by using CARP's theoretical framework. CARP has been used in the past to understand the dynamics of dissident and state action in social protest, insurgent participation in 
rebellion and the dynamics of civil wars (Francisco, 2009; 2010; Weinstein, 2007; Brown, 2013a). The literature on social media, though making mention of the collective action problem has not investigated CARP as means to understand the relationship between social media and social protest. My goal is to examine the way in which collective action theory can present a more robust theoretical understanding of how social media facilitates social protest. In order to do this I spend the next few paragraphs discussing the areas of disagreement between CARP and what Lichbach (1998a) refers to as structural theories of mobilisation, or SPOT.

Collective action theorists assume that individuals, especially when engaging in dissent, are self-interested and strategic (Olson, 1965; Lichbach, 1998b). When it comes to fostering collective action, actors face the problem of public goods and free riding, meaning that an individual's desire for the public good, alone, is insufficient for her to engage in collective action. Most people prefer to remain at home, hoping someone else will attend the protest and attain the public good for them. Thus few attend the protest and the public good remains unattained. Lichbach's five percent rule (Lichbach, 1998b; Ainsworth, 2002), which stipulates that $95 \%$ of the time less than five percent of a public good's supporters will engage in collective action, supports the obstructive nature of self-interest in the creation of mass movements and mass protest. Hence wouldbe protesters are left facing a collective action problem. The main contribution of CARP towards understanding all forms of collective dissent is in its ability to explain collective action through the solutions dissidents use to overcome their collective action problem (Lichbach, 1998b).

On the other side from this perspective is the structuralist approach (Tilly, 1978; McAdam et al., 1996; McAdam et al., 2001). This approach places an emphasis on the opportunity structures available to would-be dissidents and the mobilising structures within the society. Structurally created stratifications, such as class, gender, ethnic and racial divisions are assumed to allow coordination within the populace. Within those certain groups generated by stratification are cultural frames through which members of the group are assumed to be able to legitimate and motivate collective action (McAdam et al., 1996; Lichbach, 1998a). From this approach, understanding protest and collective action relies on looking at how groups in a society are structured and under what circumstances and for what public goods is collective action deemed legitimate.

In the following section I discuss in further detail why relying on the structuralist approach to explain the importance of social media in facilitating collective action continues to produce an incomplete understanding of social protest. What I show is that the structuralist approach assumes away the collective action problem with the presence of stratifying structures and cultural frames, while CARP, on the other hand, is able to incorporate the importance of community, whether it is based on race, gender, occupation, ethnicity or any other stratifying structures, into the possible solution groups that dissidents use to overcome their collective action problem. Looking at the influence of social media from the perspective of CARP provides us with a more theoretically robust basis to appreciate how social media is able to facilitate mass protest. 
The limitation with structural theories of protest from a CARP based perspective is that they tend to overlook the agency of individual actors in strategically creating, fostering and mobilising protest. At its worst, structural theories regard opportunity and mobilising structures in a manner where certain mobilising structures act as the invisible hand of protest. Social movements, and protest groups based on class, ethnicity or gender are thought to form spontaneously. The limitation in this approach is that in its conceptualisation is the assumption that technology, resources, or mobilising structures are able to create a great concern for the public good, and that this concern alone is capable of mobilising individuals into action. In the case of some of the research on social media the same limitations exist. For example, Lance Bennett and Alexandra Segerberg (2012) introduce the idea of connective action as an explanation for mobilisation. In this concept it is assumed that connectivity itself overcomes the collective action problem. The guiding notion behind connective action is that through social media the cultural and identity frames discussed by McAdam and colleagues (2001) become more personalised to the user. Bennett and Segerberg (2012) offer that two elements constitute connective action. These are: first "political content in easily personalised ideas" that allow individuals to easily understand how they should feel about a common problem (Bennett and Segerberg, 2012: 744). The second involves,

Various personal communication technologies that enable sharing these themes. Whether through texts, tweets, social network sharing, or posting YouTube mashups, the communication process itself often involves further personalisation through the spreading of digital connections among friends or trusted others. Some more sophisticated custom coordinating platforms can resemble organisations that exist more online than off. (Bennett and Segerberg, 2012: 744)

While the first one seems hard to differentiate between the slogans generally used by protesters and dissidents, this second element raises the most pressing question concerning social media and forms of collective dissent, can online networks via social media, like Facebook and Twitter, function as a small group or community does offline?

The reason this is important is given the fact that the collective action problem is less of a problem in small groups. In small groups participation is easier to monitor and thus prevents one's proclivity to free ride. Individuals are less likely to free ride if there is a form of social sanction associated with sitting on the side lines during the action. Related to this idea is that within small groups, or, as Lichbach refers to them (1998b), communities, communication is the antecedent of action. If group members understand what other group members plan to do, that is the action is premeditated, then group members are more likely to act collectively, especially in the case where members are assigned a given role or expectation in that action. From this perspective we see that the very characteristics of mass mobilisation, its large size and the anonymity among the masses, are the very things that prevent it from developing.

One way in which social media may be able to assist in overcoming the collective action problem is if it is able to expand the size of the group through the ease of communication while simultaneously continuing to operate with the same small group dynamics. Much of the literature explores the antecedent use of social media and the development of 
physical social protest (Barbera et al., 2015; Gil de Zúñiga et al., 2012; Bastos et al., 2015; Bastos et al., 2014; Tufekci and Wilson, 2012), however, the specific question of whether small group dynamics, such as social sanction and commitment are operating as the motivators to participation, as far as I can tell, have not really be explored.

Some may take issue with the need to question the relationship between online groups and small group dynamics, arguing that online forms of collaboration already demonstrate that individuals, through the use of social media and technology, more easily overcome the free rider problem than economists and rational choice theorists observe (or assume) in the offline world. Certainly the evidence shows that online collaboration may not operate within the same logic of free riding. Open source software and websites like Wikipedia are examples; however, it is important to point out that in these cases collaboration can be its own reward, especially when the costs and risks are minuscule. A programmer who enjoys programming and writes open source software should not be readily compared to a protester facing Egypt's riot police just because both of them are now able to coordinate their activities online.

The issue with Bennett and Segerberg's (2012) connective action thesis, and other structural approaches in general, is that it operates on the assumption that caring for the public good will induce one to participate in its acquisition, which counters the premise of Mancur Olson's (1965) theory of collective action and CARP's entire perspective. Moreover, by assuming away the collective action problem we may be missing an area where we can expand the literature's theoretical understanding of the relationship between social media and participation in social protest.

While collective action research acknowledges that you will always have zealots whose commitment, own selective incentives, such as being a full-time activist or wouldbe leader in the resistance movement, and collective actions operate with small group dynamics, are all capable of pushing these individuals onto the streets, the central question to social protest, both those that use social media, and those that predate social media, is how is that commitment spread and shared in a way that attracts nonzealots to take part in social protest. From this perspective the logic underscoring the concept of connective action seems limited as it assumes connectivity motives action. Moreover, the literature on social media and social protest, for the most part, looks at the possibilities and ease online social media has brought to organising, while overlooking the high costs that remain for collective dissent in many of the places that have witnessed the Twitter Revolutions. After all, Egypt, Tunisia, Syria and Iran are and were some of the most dictatorial and repressive regimes in the world.

\section{INCORPORATING SOCIAL MEDIA INTO COLLECTIVE ACTION THEORY}

In theorising about solutions to the dissidents collective action problem, collective action theory (Lichbach, 1998b; Ferrara, 2003; Francisco, 2009; 2010; Brown, 2013a) uses four solution categories and 21 solutions through which dissidents can overcome their 
dilemma and expand mobilisation for a public good beyond the participation of zealots. These categories are market, community, contract and hierarchy. In Lichbach's game theoretic formulations (Lichbach, 1996), demonstrated empirically by Ferrara (2003) and Brown (2013b), it takes solutions from at least two different categories of solution groups in order to solve the dissident collective action problem. For example, solutions from market solutions work in tandem to hierarchy solutions. That is market solutions can assume a preexisting organisation or a preexisting community. All of this will be further explained and understood as the paper progresses.

In the following sections I identify seven solutions to the collective action problem and discuss how each solution can theoretically interact with social media in solving the dissident collective action problem (see Table 1). These are: lower costs; increase the probability of winning; increase the probability of making a difference; common knowledge; common values; locate principals and patrons; and mutual exchange (Lichbach, 1998b). This is not necessarily an exhaustive use of the CARP's solution categories, rather the solutions discussed are the one's that seem most applicable to orienting our theoretical understanding of collective action and social media. In some cases social media may provide an easier means for dissidents to utilise a solution for mobilising. In other cases it is the solution that can enhance the effects of social media on dissident mobilisation.

Table 1. Categories and Solutions to the Collective Action Problem

\begin{tabular}{|c|c|}
\hline Solution Categories & Solutions that interact with social media \\
\hline Market & $\begin{array}{l}\text { Lower costs; Increase the probability of winning; } \\
\text { Increase the probability of making a difference. }\end{array}$ \\
\hline Community & Common knowledge; Common Values \\
\hline Hierarchy & Locate principals and patrons; \\
\hline Contract & Mutual exchange \\
\hline
\end{tabular}

\section{Market solutions}

The first category, market, operates on the cost/benefits to participating in collective dissent. Given the collective action problem, or individuals' non contribution towards the public good, market solutions look at how exogenous variables to the equilibrium of the collective action problem can alter an individual's decision calculus to participate. The costs to collective dissent are particularly important in understanding the how and why of mobilisation. Costs help constrain individual's preferences. As costs are altered, preferences and thus the proclivity to act are also adjusted (Lichbach, 1998b).

Social media can help with dissident communication; however, the reasons they wish to communicate have not changed as a result of the Internet age. Market solutions to the dissident collective action problem concern communication outside of the dissident organisation. The already organised dissidents need to inform would-be dissidents about 
the protest event. Information can change or inform an individual's decision calculus. This is clearly evident in market category solution groups that involve dissidents lowering costs, increasing the probability of winning, and increasing the probability of making a difference, all of which can lead to increased mobilisation.

Social media can facilitate lowering the costs of participating in several ways. Social media and the Internet have lowered the costs of communication. In the past dissidents had to pay for texts, tracts and pamphlets, and organisations had to pay for advertising. This placed at least some form of cost just on entering the marketplace of contentious politics, assuming first a preexisting organisation with some form of financial resources. Blogs, Twitter, Facebook, Instagram and other forms of social media are all free avenues to publicise and share a dissident or dissidents' message. In this way entry level financial costs of communication are nearly nonexistent.

Social media also lowers opportunity costs. Opportunity costs are the time, effort and energy spent on collective dissent that could be spent doing something else. This can range from having to choose to attend a meeting instead of watching your favourite television show, to the time and preparation it takes to avoid state surveillance if you decide to attend a clandestine dissident meeting. With near instantaneous communication, users no longer have to coordinate in person or at meetings.

Dissidents can also communicate with their distant counterparts in ways that were unimaginable a few decades ago. Partaking in an online chat requires less commitment of time and energy than having to physically attend a meeting. Moreover, in authoritarian systems this ability may lower the cost in terms of repression. Dissidents can meet online, often anonymously, without having to risk the danger and surveillance that comes with groups of people meeting in person. For example, organisers involved with the collective Anonymous and its first major campaign, Operation Chanology (a online and offline protest campaign against the Church of Scientology) engaged in lengthy discussions over missions, or Ops, tactics and targets via Internet Relay Chats (Coleman, 2014). Without the Internet and this ease of communication, and its space away from state surveillance, Anonymous would never have been able to coordinate its first protests against the Church of Scientology (Coleman, 2014).

While the Internet has helped dissidents communicate with each other, social media allows dissidents to share their message with a broader world in a way that is low cost, and open. For example, during Operation Chanology, Anonymous posted a video entitled "A Message to Scientology" on Youtube. The video has attracted five million views and helped the overall operation, and Anonymous, attract considerable media attention (Coleman, 2014). Protests all around the world generate hashtags users can follow. Dissidents still face the problem of getting their message beyond their core followers. Barbera and colleagues (2015) find that periphery supporters online are key to disseminating information to a larger audience. Just as the advent of the Internet has lowered costs for businesses and firms by bringing faster and easier forms of communication, so too has social media reduced the costs of engaging collective dissent. 
Secondly, social media helps increase the dissident's belief in the probability of winning by reporting the protest event in real-time to an expanded audience. As events transpire, users are able to react, respond and witness what is happening even without being present at the protest event. Recent research (Barbera et al., 2015) found that during the Gazi park protest in Istanbul in 2013 dissidents at the centre of the protest, at its core, were able diffuse real-time information to a periphery of supporters, whose own engagement worked to disseminate this information further. This was especially important given that the Turkish media was not covering the protests. The researchers empirically observe how social media was able to circumvent the censored Turkish media, through speed and online diffusion, gaining international attention.

The ability to see a protest as it unfolds can greatly increase the chances that nonparticipants will chose to participate. As Lichbach observes: "as a dissident's estimate of the chances of victory increases, his or her participation in collective dissent also increases" (1998b: 62). Social media helps communicate victories quickly through live tweeting, updating posts, or making short videos or live streaming through various social media, assisting the chances of increasing participation.

Of course, this can go the other way. Witnessing repression or failures can have a reverse effect; however, dissidents and dissident leaders want to increase the belief in the probability of winning and therefore will manipulate facts and events to suit their goals. This is often why dissident numbers at protest events are inflated, while the state tries to diminish such numbers. In our contemporary world, a photo tweeted by protesters at an event can help more likely-protesters participate in that event in a time-frame that more quickly reaches the intended audience than was likely the case when the dispersion of visual images was dependent on traditional media.

The next solution is: increase the probability of making a difference. This solution plays to the importance individuals place on their own efficacy. Social psychology has shown that among crowds individuals feel a diffusion of responsibility enabling them to look to someone else to act in the time of a crisis (Darley and Latane, 1968). For this reason, collective action also suffers from large groups as individuals believe someone else will take care of the problem for them. Therefore dissidents and dissident leaders want to convince individuals that their participation is crucial to success. The question here is, how can social media facilitate increasing individuals' efficacy?

So far, I have argued that the value of social media to dissidents is that it provides them with information once impossible to attain during the protest. However, information on social media prior to the protest may also assist in mobilising individuals by accentuating their ability to make a difference. For example, imagine an event organised on social media where users are able to commit to attending visibly, and other users are able to see the number of people who have committed to attend the protest event. Such a situation helps individuals understand that their attendance is crucial to the success of the event. The lower the number, the more an individual can understand the importance of her attendance. She can even be efficacious by inviting others to the event or by spreading 
the news that the event is happening in the first place. Such actions, and their ease via social media can lead to feelings of individual importance amid the masses that instances of collective dissent try to muster.

One possible problem for dissidents on social media concerns how little or how much individuals must do in order to feel efficacious. Does simply sharing a tweet or liking a post satisfy their feelings of efficacy, thereby lowering the likelihood that an individual may attend a protest after feeling useful simply by sharing and stating an opinion about it online? Evgeny Morozov (2009) argues that such acts are low-cost and low impact, and essentially meaningless, while creating a good feeling for the actors. In this sense social media may increase feelings of efficacy, while also stripping away a would-be dissident's actual effectiveness. If liking the protest satisfies as much as attending the protest, then social media may actually reduce effective efficacy among dissidents.

Yannis Theocharis (2015) parses the debate by offering that liking or retweeting are not sufficient instances of political action, but rather represent aspects of preference sharing. Actions that involve posting symbolic photos, tweeting to politicians and policy makers, or sharing posts can represent actions (Theocharis, 2015), and it could be argued, do increase feelings of efficacy that further dissidents' goals and causes, especially when considering that research shows that users sharing information from the core dissidents concerning an event likely helps dissidents attract more attention and possibly participants (Barbera et al., 2015). Gil de Zúñiga and colleagues' (2012) study of protest in Chile explored which types of online activity shared a strong relationship with protesting, and found that users who used social media for expressing opinions and joining causes were more likely to protest. It seems then that rather than siphon off efficacious feelings, it enhances them, leading towards greater participation both online and offline.

Returning to the access of the actual protest event via social media we see that increasing efficacy too can lead to increases in participation. As Lichbach notes: "as the dissidents and regime move closer to each other in strength the probability of a single dissident making a difference in the conflict increases. Collective dissent thus becomes more likely" (1998b: 84). Sharing with users the confrontational aspects of an event, both in its lead up and as it unfolds, can likely help propel people to participate.

Again, we see how the instantaneousness of social media, coupled with the fact that the dissidents control the message as opposed to the news media, who dissidents used to depend on in order for an event to be reported, helps us understand how an individual's feelings of efficacy can be increased by following events via social media. Even if nonparticipants fail to participate during a live event, witnessing the event, and learning about what transpired during the event can lead to their future participation (Francisco, 2004).

To summarise, the relationship between the market solutions discussed above and social media is one in which we can understand the potential for social media to effectively aid dissidents' efforts to solve the collective action problem through lowering the costs 
of communication, bettering dissident's ability to communicate an imminent victory, and increase feelings of efficacy. And while the literature offers that online activity seems to increase feelings of efficacy, it would be beneficial if future work dealt with question specifically and further explore the extent to which an individual's efficacy is satisfied by simply engaging with dissident content online or whether the desire to be efficacious is transferable to the offline world.

\section{Community solutions}

The next and most likely solution group to aid dissidents on social media is the community solution group. The solutions of common knowledge and communication explore how communication within a given community can alter how members of that community act collectively (Lichbach, 1998b). Communication helps organise and coordinate dissidents by fostering mutual expectations within a certain community. The community category solution groups of common knowledge and common values are likely to be enhanced by the use of social media, while also assisting dissidents in solving their collective action problem.

Clearly, communication among dissidents is essential to mobilising, and the community category of solutions to the dissident collective action problem addresses the impact of communication directly. The first solution, common knowledge, argues that communication concerning protests will assist in aiding protest. The reason for this is the way in which preexisting communication can prepare dissidents for action. Knowing that if an individual acts, she will not act alone is very important for collective action. Moreover, communication prior to an event can tell dissidents the time and place of the event, and what circumstances may trigger a protest (common knowledge). A mutually understood signal concerning not just when to act, but how to act can also serve as the necessary antecedent to action (common values). In the online world this communication can be carried out among members of a group, followers of a particular profile, or users that interact with each other. It is clear that social media and the Internet can assist dissidents in communicating and coming to understand and agreeing on what type of actions or events can trigger a collective response. While dissidents have been able to communicate long before the advent of the Internet, we see that when coupled with the market solution category of lowering costs, communication is facilitated by online means of communication, which in itself, facilitates more communication, thereby increasing the likelihood of protest.

One of the pressing empirical questions for social media and protest is, how cohesive can online groups be? As mentioned in a previous section, the ability of an online community to function like a small group in which the members know and rely on each other, permitting elements of social sanction against members who fail to participate, and a cohesive environment in which communal obligation is shared among members is an empirical question. Evidence shows that in small, in-person groups these norms do develop (Olson, 1965), and can lead dissidents to act collectively (Brown, 2013b; Lichbach, 1998b). If such relationships do exist among online groups, then we can understand how the use of social media is a great boon to dissident communities. The low cost of 
coordination and the easy means to produce common knowledge, contribute to the likelihood of collective dissent when social media is involved.

The relationship between the community solutions discussed above and social media is one in which we can appreciate the ease at which communities can communicate and share common knowledge and common values online to manifest itself in stronger communities, thereby increasing individuals' chances of knowing when to act and how to act collectively. The question that remains is, are large and small online communities too diffuse to operate and behave with the the same cohesiveness and norms as small, offline communities when it comes to engaging in social protest? Moreover how do the dynamics of social sanction work when group members can be anonymous?

Anecdotally, we can see elements of norms and social sanction at play among the most, no pun intended, anonymous members of the group Anonymous. During Operation Chanology, a subset of Anonymous members, referred to as the marblecake collective, produced propaganda, press releases and facilitated communication between different groups. Among the eight or so members of the collective one member violated a set of norms that existed both within the collective and within the broader populace of Anonymous, namely by trying to force the support of an action that many members seemed opposed to. As a result, the member herself became a target, and other members spread rumours about her and also released her personal information, known as doxing (Coleman, 2014: 72-73).

What this story reveals is that norms or values within online communities develop and violating those norms can have negative repercussions. At the same time, it is curious that one of those repercussions involves removing a user's anonymity by releasing personal, biographical information. Accepting that community solutions are often a necessary way of solving the collective action problem invites researchers to explore the dynamics of online communities, their norms, and boundaries, how their members relate to one another and how these aspects develop into solutions to the dissident's collective action problem.

\section{Hierarchy solutions}

The next solution category assumes a preexisting organisation. Just as community solutions assume a community, hierarchy assumes an organised dissident entity, that is more often than not, hierarchical, meaning it has leaders. The hierarchy category of collective action solutions is important as it coincides with both market and community solutions. That is, a preexisting organisation is the 'visible' hand that lowers costs, provides information, and increases efficacy. As it relates to social media and online activism, the preexisting organisation, even if decentralised like the hacker group Anonymous, has more active members that disseminate information online, post photos designed to lower costs, increase efficacy, or share common knowledge. With social media, the issue of leadership remains important, but seems to have been overlooked by the literature. Whether or not the revolution will be tweeted depends on who is doing the tweeting. 
Therefore, we must first recognise that tweets and posts come from someone. The use of social media assumes that there already exists an interested party acting for the public good. Turnout for an event can likely be linked to the size and type of that organisation. For example, imagine the labor union the AFL-CIO tweeting the time, location and cause of a worker's rally versus your local Anarchist collective tweeting the same event. The AFL$\mathrm{CIO}$ has 12 million members, 88 thousand followers on twitter, a SuperPac and allies in the halls of the US Congress. Clearly an event announced on social media by the AFL$\mathrm{ClO}$ will receive more notice than an event from a lesser organisation. The bigger the size of the preexisting organisation, the more likely its message will trend or pick up interest from third parties, as media and other well known profiles, retweet or comment on the original message. Therefore, in focusing on the theoretical understanding of social media and mobilisation it is necessary to note the type and size of the organisation operating on social media. When it comes to empirically testing the influence of social media on protest, an important research question is, does who and how big an online entity is in the real world, likely effect the number of participants on the street?

While Barbera and colleagues (2015) discuss the importance of spreading protest information flows from the core to the periphery, the authors do not explore who or what organisations the core are comprised of. Yet, who is tweeting the tweets might play a important factor in how the information is further disseminated. By understanding the importance of hierarchy solutions to the dissident collective action problem, we can also understand the importance of focusing on who organises, composes and posts the original dissident messages on social media, and its consequences for participation.

At the same time small dissident organisations can likely make use of social media in finding and locating supporters for their cause. This brings us to one of the most important hierarchy solutions to the dissident collective action problem, finding and locating principals and patrons (Walker, 1983; Lichbach, 1998b). In the world of protest, patrons offer material resources to dissident organisations. While, principals offer skills, know how, and other resources to dissident organisations. Francisco (2010) observes that in most cases, dissident leaders come from a higher socio-economic background than their followers, indicating that their education and resources help their efforts at organising and mobilising.

Financing from patrons, wealthier individuals or organisations, helps social movements attain, otherwise, costly resources for dissent. This money can be used to finance full-time activists, help purchase resources that help lower costs, or provide other solutions to the collective action problem. One example of a dissident organisation receiving patronage is the Centre for Peace Studies in Croatia, which is funded by the EU, and even the Croatian state, and yet often engages in dissident and protest activities. On a more negative and violent side, it is well established that wealthy Gulf States have served as patrons to Islamist terror organisations, helping finance Hamas, Al Qaeda, the Islamic State, and the AI Nursa Front, to name a few. Patronage is a tried and true solution to the dissident collective action problem. 
The question here is, who is considered a patron on social media, and how can their patronage help with dissident mobilisation? I explore answers to this question in two ways. The first looks at material and financial contributions. Here we see how the Internet and social media can help individuals and organisations raise money for their cause via crowdfunding services, such as gofundme, Patreon, and kickstarter. For example, in 2016, protesters of the North Dakota Access Pipeline raised over one million dollars via crowdfunding (Associated Press, 2016). The money was used to house and feed 670 protesters as the North Dakota winter took hold on the protesters' camp (Associated Press, 2016).

The ability to crowd source funding via the Internet means that anyone in the world can easily contribute to a cause they care about. Prior to the Internet, dissidents had to organise their own fundraisers, meet in person with benefactors, and provide selective incentives to donors. For example the organisation Green Peace raised funds for its first campaign to the island Amchitka from a concert in 1970 featuring the popular folk artists Joni Mitchell and James Taylor. Now, one can imagine how much more difficult it is to organise a concert than setting up a fundraising campaign on a preexisting online platform. We can also assume then, that online forms of fundraising lead to easier access to material resources, which leads to more easily aiding dissidents' mobilisation efforts.

The second form of patronage is more virtual than material, and that is when prominent organisations or individuals online, those with a strong following, or support, disseminate a dissident group's message, actions or information to their followers via Facebook likes, posts, retweets or other means of online sharing. For example, Leonardo Dicaprio tweeted his support for the protesters in North Dakota to all of his 17 million followers. His tweet received 3524 retweets, 6874 likes, and 337 replies. At the same time his tweet itself became the subject of several news stories, mentioning his and others support for the small group of protesters in North Dakota. Another example involves actress and movie star Shailene Woodley, who visited the protest site in North Dakota and was arrested by police during a two hour livestream to her Facebook followers (she has over one million followers). This event was not only carried live to her followers, but also garnered its own share of news stories.

The question is whether or not this form of virtual or online support contributes to the groups' mobilisation efforts? Publicity of a cause certainly matters to dissidents and therefore this online support via shares, likes, tweets and retweets, has the potential to aid the dissident group. As Lichbach explains, "Potential dissidents, because of imperfect information, might not even know that a dissident group exists. Dissident groups need in the first instance to alert dissidents to the possibility of contributing to [collective action], a course of action that might never had occurred to them" (Lichbach, 1998b: 89).

Social media, whether DiCaprio's 17 million followers or the news stories generated by his tweet in support for the North Dakota protesters, circumvents the gatekeeping of traditional media, whose editorial restriction might refrain in promoting the dissidents' cause, while also facilitating easier access to a much wider audience. Moreover, it is 
essentially cost free to the dissident organisation, whereas before the advent of social media publicity took more time and cost more. In this sense online patronage can certainly, more easily solve the dissident collective action problem. Of course, to make use of this publicity, dissidents must already have a preexisting organisation.

To summarise, the relationship between the hierarchy solutions discussed above and social media is one in which we can understand how the purpose, size and notoriety of preexisting organisations' use of social media influences physical turnout to a protest event. Furthermore the use of patrons on social media and their influence on social protest events should also be further explored. Social media has most certainly eased dissident organisations' means of finding patrons in both a material sense via fundraising, crowdsourcing platforms, and in a virtual sense via publicity from well followed and known online entities.

\section{Contract solutions}

Contract solutions involve the evolution of spontaneous acts of dissent into established normative institutions that come to govern dissidents' behaviour amid their collective endeavours. The literature sites peasant communes, Soviets, revolutionary parties, committees, and church groups (Lichbach, 1998b: 129; Wood, 2003). With the Internet serving as a new environment for connectivity, forms of individual and collective action, as well as communication, we can easily see how new norms and institutions not only develop, but are needed to govern behaviour in cyberspace. In terms of online activism, especially among 'Hacktivist' groups like the decentralised Anonymous, institutionalised norms seem to be very important in facilitating collective dissent. As one author describes,

Anonymous is a classic 'do-ocracy', to use a phrase that's popular in the open source movement. As the term implies, that means rule by sheer doing: Individuals propose actions, others join in (or not), and then the Anonymous flag is flown over the result. There's no one to grant permission, no promise of praise or credit, so every action must be its own reward. (Norton, 2011)

As idealistic as this sounds, it is difficult to accept that individuals just act regardless of whether or not they expect others to do the same. While members of Anonymous may not expect material rewards or incentives for their participation, they do not exist in a vacuum. This is where the idea of institutionalised norms seems crucial to the functioning of online dissent, namely an established norm of reciprocity. Lichbach (1998b) offers that dissidents may engage in a regimen of mutual exchange, in which an individual's support for a form of dissent will be reciprocated by others' support for her act of dissent. In the online world, established norms of reciprocity can aid in the exchange of acting collectively in support of certain causes among dissidents. Anonymous' operations in which individuals from all over the Internet engage in hacking certain targets, from the mobile phones of alleged rapists, to Denial of Service Attacks that bring down targeted websites, to the release of a target's personal information to as many locations on the Internet as possible are organised through this corner of the Internet's norms of reciprocity. That is, if one member, or a set of members begin the acts they know others will assist and visa-versa. 
In the case of Anonymous, these norms developed not out of collective dissent, but first out of spontaneous acts of pranking, for the 'lulz'. Through the act of pranking, the norms of reciprocity became ingrained within the Anonymous online community and have since led to further, more elaborate, choreographed dissident actions on the Internet (Coleman, 2014).

In this sense we can see how the Internet, as a space for collaboration that is not constrained by geography and one that has become its own virtual world, led to the establishment of norms among certain users. Message boards on the websites 4chan and subreddits on Reddit have often developed their own culture and norms of expected behaviour (Trammel, 2014). Out of such entities, groups like Anonymous have formed and engaged in online and offline collective action.

The question then is, how does this online activity relate to mass protest on the streets and squares of cities? Here we see the evidence of how solving the dissident collective action problem requires at least two solutions from two different solution groups. A group like Anonymous, acting online can both serve as a preexisting organisation or as a patron to other organisations, while at the same time members of Anonymous, whose norms of reciprocity have already been established may form a smaller community in which community solutions work more effectively, and decide to move their online dissent offline and to the streets. Evidence of this already exists as we saw members, or purported members of Anonymous begin a campaign online and then engage in physical protests during Operation Chanology (Coleman, 2014). More recently, events like the Anonymous organised 'Million Mask March' on 5 November, Guy Fawkes Day, in the UK attracted 20 thousand protesters (Gayle, 2016).

To summarise, the relationship between the contract solutions discussed above and social media is one through which we can understand social media's influence in effectively aiding dissidents' efforts to solve the collective action problem through the establishment of norms of mutual exchange between actors online. The question that remains is how easily are norms of online exchange and collaboration transferable to the offline world? And what processes or other collective action solutions are involved in this transfer?

\section{CONCLUSION}

This paper has attempted to demonstrate how integrating the theoretical framework of the Collective Action Research Program with the research on the link between social media on social protest could provide a useful orientation to better understand the theoretical foundations of this relationship. Out of the 21 solutions to the dissident collective action problem developed by Lichbach (1998b) and used in much of the literature on social protest, I have focused on seven solutions from all four solution groups and attempted to theoretically understand how their relationship with dissidents, wouldbe dissidents, and dissident organisations can be influenced by social media. Placing the 
relationship of social media and protest within CARP can offer the literature a theoretical consensus that seems to be currently lacking. At the same time it can offer a more robust and complete theoretical framework by overcoming the shortcomings in the structuralist approach (SPOT).

Online activism and social media offer a very fruitful area of research for contentious politics. With the online presence of such a vast amount of information and the ability to track and observe the audiences' response to that information, incorporating social media into collective action research has the potential to better inform our own understanding of social protest and dissident behaviour in general.

\section{References}

$>$ Ainsworth, Scott H. (2002) Analyzing Interest Groups : Group Influence on People and Policies. New York: Norton.

$>$ Associated Press (2016) Dakota Access Pipeline Protesters Crowdsource for $\$ 5,000$, Get $\$ 1$ Million. CBS News. http://www.cbsnews.com/news/dakota-access-pipeline-protesters-crowdsource-5000get-1-million/ (21.03.2017).

>Barbera, Pablo; Wang, Ning; Bonneau, Richard; Jost, John T.; Nagler, Johnathan and Tucker, Joshua (2015) The Critical Periphery in the Growth of Social Protests. PLoS ONE 10 (11). DOI: 10.1371/journal. pone.0143611.

>Barry, Ellen (2009) Protests in Moldova Explode, With Help of Twitter. The New York Times. http:// www.nytimes.com/2009/04/08/world/europe/08moldova.html (03.03.2017).

>Bastos, Marco T.; Mercea, Dan and Charpentier, Arthur (2015) Tents, Tweets, and Events: The Interplay Between Ongoing Protests and Social Media. Journal of Communication 65 (2): 320-350. DOI: $10.1111 /$ jcom.12145.

>Bastos, Marco Toledo; Recuero, Raquel da Cunha and da Silva Zago, Gabriela (2014) Taking Tweets to the Streets: A Spatial Analysis of the Vinegar Protests in Brazil. First Monday. http://journals.uic. edu/ojs/index.php/fm/article/view/5227 (28.03.2017). DOI: 10.5210/fm.v19i3.5227.

>Bennett, Lance W. and Segerberg, Alexandra (2011) Digital Media and the Personalization of Collective Action: Social Technology and the Organization of Protests against the Global Economic Crisis. Information, Communication \& Society 14 (6): 770-799. DOI: 10.1080/1369118x.2011.579141. $>$ Bennett, Lance W. and Segerberg, Alexandra (2012) The Logic of Connective Action: Digital Media and the Personalization of Contentious Politics. Information, Communication \& Society 15 (5): 739 768. DOI: 10.1080/1369118x.2012.670661.

>Breuer, Anita; Landman, Todd and Farquhar, Dorothea (2015) Social Media and Protest Mobilization: Evidence from the Tunisian Revolution. Democratization 22 (4): 764-792. DOI: 10.1080/13510347.2014.885505.

>Brown, Cody McClain (2013a) Why Do They Fight? Explaining Participation in the War in Croatia. Doctoral Dissertation. Lawrence: University of Kansas.

>Brown, Cody McClain (2013b) Who Fights First: Greivances, Community and Collective Action. Politička misao: Croatian Political Science Review 50 (5): 7-28.

>Coleman, Gabriella (2014) Hacker, Hoaxer, Whistleblower, Spy: The Many Faces of Anony-mous. London: Verso books.

>Conover Michael, D.; Ferrara, Emilio; Menczer, Filippo and Flammini, Alessandro (2013) The Digital Evolution of Occupy Wall Street. PLOS ONE 8 (5). DOI: 10.1371/journal.pone.0064679.

$>$ Darley, John M. and Latane, Bibb (1968) Bystander Intervention in Emergencies: Diffusion of Responsibility. Journal of personality and social psychology 8 (4): 377-383. DOI: 10.1037/h0025589. >Delany, Colin (2011) How Social Media Accelerated Tunisia's Revolution: An Inside View. http://www. huffingtonpost.com/colin-delany/how-social-media-accelera_b_821497.html (28.03.2017). 
$>$ Ferrara, Federico (2003) Why Regimes Create Disorder: Hobbes's Dilemma during a Rangoon Summer. The Journal of Conflict Resolution 47 (3): 302-325. DOI: 10.1177/0022002703252366. >Francisco, Ronald A. (2010) Collective Action Theory and Empirical Evidence. New York: Springer. DOI: 10.1007/978-1-4419-1476-7.

$>$ Francisco, Ronald A. (2009) Dynamics of Conflict. New York: Springer. DOI: 10.1007/978-0-38775242-6.

$>$ Francisco, Ronald (2004) After the Massacre: Mobilization in the Wake of Harsh Repression. Mobilization: An International Quarterly 9 (2): 107-126.

$>$ Gayle, Damien (2016) Million Mask March: Police Curb Protests amid Fears of Violence. The Guardian. https://www.theguardian.com/technology/2016/nov/04/million-mask-march-policeprotesters-violence-fears-restrictions (21.03.2017). >Gerbaudo, Paolo (2012) Tweets and the Streets: Social Media and Contemporary Activism. London: Pluto Press.

>Gil de Zúñiga, Homero; Nakwon, Jung and Sebastián, Valenzuela (2012) Social Media Use for News and Individuals' Social Capital, Civic Engagement and Political Participation. Journal of ComputerMediated Communication 17 (3): 319-336. DOI: 10.1111/j.1083-6101.2012.01574.x.

$>$ Gladwell, Malcom (2010) SMALL CHANGE Why the Revolution Will Not Be Tweeted. The New Yorker. October 4, 2010: 42-49.

$>$ Grossman, Lev (2009) Iran Protests: Twitter, the Medium of the Movement. Time. http://content. time.com/time/world/article/0,8599,1905125,00.html (03.12.2016).

>Lichbach, Mark Irving (1998a) The Rebel's Dilemma. Ann Arbor: University of Michigan Press. DOI: 10.3998/mpub.13970.

>Lichbach, Mark Irving (1998b) Contending Theories of Contentious Politics and the StructureAction Problem of Social Order. Annual Review of Political Science 1 (1): 401-424. DOI: 10.1146/ annurev.polisci.1.1.401.

>Lichbach, Mark Irving (1997) Mobilization Forum: Response to Mcadam, Tarrow, and Tilly. Contentious Maps of Contentious Politics. Mobilization: An International Quarterly 2 (1): 87-98. >Lichbach, Mark Irving (1996) The Cooperator's Dilemma. Ann Arbor: University of Michigan Press. DOI: 10.3998/mpub.13808.

$>$ McAdam, Doug; Tarrow, Sidney G. and Tilly, Charles (2001) Dynamics of Contention. Cambridge: Cambridge University Press. DOI: 10.1017/cbo9780511805431.

$>$ McCarthy, John D. and Zald, Mayer N. (1977) Resource Mobilization and Social Movements: A Partial Theory. American Journal of Sociology 82 (6): 1212-1241. DOI: 10.1086/226464.

$>$ Morozov, Evgeny (2009) From Slacktivism to Activism. Foreign Policy. http://foreignpolicy. com/2009/09/05/from-slacktivism-to-activism/ (28.02.2017).

$>$ Norton, Quinn (2011) Anonymous 101: Introduction to the Lulz. Wired Magazine. https://www. wired.com/2011/11/anonymous-101/ (28.02.2017).

>Olson, Mancur (1965) The Logic of Collective Action: Public Goods and the Theory of Groups. Cambridge, Mass: Harvard University Press.

$>$ Segerberg, Alexandra and Bennett, Lance W. (2011) Social Media and the Organization of Collective Action: Using Twitter to Explore the Ecologies of Two Climate Change Protests. The Communication Review 14 (3): 197-215. DOI: 10.1080/10714421.2011.597250.

$>$ Merriam-Webster (2017) Social Media. www.merriam-webster.com/dictionary/social media. (28.02.2017).

$>$ Theocharis, Yannis (2015) The Conceptualization of Digitally Networked Participation. Social Media+ Society 1 (2): 1-14. DOI: 10.1177/2056305115610140.

$>$ Tilly, Charles (1978) From Mobilization to Revolution. Reading, Mass.: Addison-Wesley Pub. Co. $>$ Trammell, Matthew (2014) User Investment and Behavior Policing on 4chan. First Monday 19 (2). http://ojphi.org/ojs/index.php/fm/article/view/4819/3839 (28.02.2017). DOI: 10.5210/fm.v19i2.4819. $>$ Tufekci, Zeynep and Wilson, Christopher (2012) Social Media and the Decision to Participate in Political Protest: Observations from Tahrir Square. Journal of Communication 62 (2): 363-379. DOI: 10.1111/j.1460-2466.2012.01629.x. 
$>$ Tufekci, Zeynep (2014) The Medium and the Movement: Digital Tools, Social Movement Politics, and the End of the Free Rider Problem. Policy \& Internet 6 (2): 202-208. DOI: 10.1002/1944-2866. poi362.

$>$ Walker, Jack L. (1983) The Origins and Maintenance of Interest Groups in America. The American Political Science Review 77 (2): 390-406. DOI: 10.2307/1958924.

$>$ Weinstein, Jeremy M. (2007) Inside Rebellion: The Politics of Insurgent Violence. Cambridge:

Cambridge University Press.

$>$ Wolfsfeld, Gadi; Segev, Elad and Sheafer, Tamir (2013) Social Media and the Arab Spring. The International Journal of Press/Politics 18 (2): 115-137. DOI: 10.1177/1940161212471716.

$>$ Wood, Elisabeth Jean (2003) Insurgent Collective Action and Civil War in El Salvador. Cambridge: Cambridge University Press. DOI: 10.1017/cbo9780511808685. 


\section{TVITOVI I MOBILIZACIJA: TEORIJA KOLEKTIVNOG DJELOVANJA | DRUŠTVENI MEDIJ|}

\section{Cody McClain Brown}

SAŽETAK Ovaj rad ispituje odnos između građanskih prosvjeda i društvenih medija iz perspektive istraživačkog programa kolektivnog djelovanja. Dok literatura ukazuje na snažne empirijske dokaze o pozitivnom odnosu između upotrebe društvenih medija i pojave građanskih prosvjeda, teorijsko je podupiranje ovog odnosa osporavano i često neodređeno. Nastojeći pružiti snažniju teorijsku osnovu za taj odnos, ovaj rad istražuje teorije kolektivnog djelovanja fokusirajući se na društvene medije i njihovu ulogu u rješavanju problema kolektivnog djelovanja onih koji se suprotstavljaju službenoj politici. Rad promišlja kako upotreba teorije kolektivnog djelovanja za razumijevanje društvenih medija i prosvjeda može poslužiti boljem razumijevanju pozitivnog odnosa između društvenih medija i pojave građanskih prosvjeda.

KLJUČNE RIJEČI

DRUŠTVENI MEDIJI, GRAĐANSKI PROSVJEDI, PROSVJEDNA POLITIKA, TEORIJA KOLEKTIVNOG DJELOVANJA

Bilješka o autoru

Cody McClain Brown :: Sveučilište u Zagrebu, Fakultet političkih znanosti, Zagreb :: codymcclain@gmail.com 